\title{
Subdural abscess secondary to covert dental sepsis
}

\author{
MAE S. SPRotT* \\ B.Sc., M.B., B.Ch., M.R.C. Path. \\ P. K. NeWMaN $\dagger$ \\ M.B., M.R.C.P. \\ K. HALL $\ddagger$
M.B., B.S., F.R.C.R. \\ R. R. WELBURY** \\ B.D.S. \\ H. R. INGHAM* \\ M.B., Ch.B., Dip. Bact., F.R.C. Path. \\ ${ }^{*}$ Regional Public Health Laboratory, †Departments of Neurology, $\ddagger$ Neuroradiology and ** Oral Surgery, \\ Newcastle General Hospital, Westgate Road, Newcastle upon Tyne
}

\begin{abstract}
Summary
The bacterial flora of a subdural abscess in a 17-yearold male, with radiological evidence of unilateral infection of the maxillary and frontal air sinuses, was typical of that encountered in the dental sulcus. Extensive examination revealed no primary focus of infection other than apical infection in the 2 upper first molar teeth, which were extracted. Treatment with ampicillin, gentamicin and metronidazole rapidly controlled the subdural infection, and resolution, as evidenced by computerized tomography, was complete at 10 months.
\end{abstract}

\section{Introduction}

Intracranial sepsis is a well known complication of acute dental infection arising either spontaneously, or after dental surgery (Hollin, Hayashi and Gross, 1967). The relationship of chronic asymptomatic dental sepsis to intracranial infection is less firmly established. Ingham et al. (1978b) have described 2 patients with brain abscess in whom symptomless dental infection was considered to be the primary source of infection. The present authors report the clinical and bacteriological findings in a patient with subdural abscess in whom the primary source was covert dental sepsis.

\section{Case report}

A 17-year-old panel beater presented with a 2-week history of productive cough, sore throat, nausea and vomiting, followed within a day by frontal headache, gradually increasing in severity and exaggerated by straining and coughing. Three days before admission he noticed progressive weakness of the right leg, shivering and sweating. On examination, he was febrile and drowsy but not dysphasic. The right optic fundus was swollen and there was a dense, right homonymous hemianopia and pyramidal weakness of the right leg, with increased reflexes and an extensor plantar response.

The peripheral white cell count was $11 \cdot 1 \times 10^{9} / 1$, the ESR $45 \mathrm{~mm}$ in the first hour and there was hyponatraemia. Computerized tomography (CT) revealed no abnormality other than widening of the interhemispheric fissure. Lumbar cerebrospinal fluid was at a pressure of $22 \mathrm{~cm}$ and contained 16 white cells $/ \mathrm{mm}^{3}$, polymorphs and lymphocytes being in equal numbers. The CSF protein was $0.39 \mathrm{~g} / \mathrm{l}$, the sugar $4.2 \mathrm{mmol} / \mathrm{l}$ and it was sterile on culture. A further CT scan showed increased widening of the interhemispheric fissure with contrast enhancement of the edges, more on the left than the right, and partial ring enhancement in the left frontal pole, appearances consistent with a parafalcine subdural empyema.

Midline frontal, left frontal, left temporal and left posterior burr holes were made and approximately $35 \mathrm{ml}$ of thick pus aspirated. Five milligrams of chloramphenicol were instilled and a rubber drainage catheter inserted into the cavity. Two days later $5 \mathrm{ml}$ of pus were aspirated from the drainage tube which was then removed.

Culture of the pus revealed the organisms listed in the table, and a blood culture taken on the day of operation yielded anaerobic streptococci, nonhaemolytic streptococci, Streptococcus milleri (Lancefield Group F) and $S$. milleri (non-groupable).

Postoperatively, the patient received i.v. ampicillin (one $\mathrm{g} / 6 \mathrm{hr}$ ), gentamicin $(80 \mathrm{mg} / 8 \mathrm{hr}$ ) and metronidazole $(500 \mathrm{mg} / 8 \mathrm{hr})$. Examination carried out to locate the source of infection revealed no abnormality in any system other than in the right maxillary 
and frontal air sinuses which, on X-ray, were opaque. Dental examination revealed 2 grossly carious upper first molar teeth, each had radiological evidence of apical infection associated with one or more of their roots. Removal of the infected teeth was carried out.

TABLE 1. Bacteria isolated from subdural empyema

\begin{tabular}{|c|c|}
\hline Obligate anaerobes & Aerobes/facultative anaerobes \\
\hline $\begin{array}{l}\text { Propionibacterium acnes } \\
\text { Fusobacterium polymorphum } \\
\text { Veillonella alcalescens } \\
\text { Bacteroides melaninogenicus } \\
\quad \text { sub. sp. melaninogenicus }\end{array}$ & $\begin{array}{l}\text { Streptococcus milleri } \\
\quad(\text { Lancefield Group F) } \\
S . \text { milleri } \\
\quad(\text { Lancefield Group C) }\end{array}$ \\
\hline Anaerobic streptococci & S. viridans \\
\hline Anaerobic diphtheroid & $\begin{array}{l}\text { Eikenella corrodens } \\
\text { Actinomyces odontolyticus }\end{array}$ \\
\hline
\end{tabular}

The patient made a steady recovery, complicated by focal epilepsy controlled by phenytoin. One month postoperatively he was clinically normal and remained so at review 18 months later. The CT scan appearance steadily improved with partial resolution of the empyema at 6 months and complete resolution at 10 months.

\section{Bacteriology}

Specimens of pus were processed within $30 \mathrm{~min}$ of aspiration. The material was inoculated on to MacConkey agar, and nutrient agar containing $5 \%$ horse blood (vol/vol), which were incubated aerobically at $37^{\circ} \mathrm{C}$, and on to chocolate agar incubated in $5 \%$ carbon dioxide at $37^{\circ} \mathrm{C}$. The pus was also inoculated on to duplicate plates of blood agar, and blood agar containing nalidixic acid at a final concentration of $50 \mathrm{mg} / \mathrm{l}$ as a selective medium (Ingham et al., 1978a), which were incubated anaerobically in an atmosphere of $90 \%$ hydrogen and $10 \%$ carbon dioxide in an anaerobic jar fitted with a cold catalyst. One set of plates was left for 5 days before examination.

Aerobic and facultatively anaerobic bacteria were identified by reference to Cowan and Steel (1974). The methods of Duerden et al. (1976) and Tharagonnet et al. (1977) were used to identify obligate anaerobes. Sensitivity to antibiotics was determined by the diffusion technique using paper discs containing metronidazole $5 \mu \mathrm{g}$ and penicillin 1 unit, appropriate controls being included.

\section{Discussion}

The bacterial flora of the abscess was typical of that found in dental abscesses (Sabiston, Grigsby and Segerstrom, 1976) and did not resemble that reported in studies of frontal lobe abscesses stated to be of sinusitic origin, in which $S$. milleri w present in pure culture (de Louvois, Gortvai and Hurley, 1977). In the absence of any other infective focus, the organisms isolated from the blood cultue almost certainly represented bacteraemia secondary to the intracranial infection.

The occurrence of maxillary sinusitis due to to extension of dental infection is well document (Bauer, 1943; Maloney, 1968). This sinus opens its ostium into the central part of the hiatus only-a few millimetres posterior to the ostium of the frontal sinus (Gray, 1967). Dental infection may thus spread to these sinuses, causing the increased radiological opacity seen in this patient, thence progressing intracranial sepsis.

Although organisms encountered in dental sepsig are usually sensitive to penicillin, this may not always be the case. Destruction of penicillin in the abscess cavity by penicillinase-producing strains Af Bacteroides melaninogenicus (Pinkus, Veto an Braude, 1968), which may be present in dentol infection (Sabiston et al., 1976), could reduce the efficacy of this agent against accompanying perf? cillin-sensitive bacteria. This effect has been demo strated experimentally in mice (Hackman and Wilkins, 1976). Since there will necessarily be delay before bacteriological results are availah initial treatment of intracranial infections must be based on the primary source of infection and the bacterial species likely to be encountered. Tise initial chemotherapy of subdural abscess should, 曾 the authors' opinion, consist of a combination of antimicrobial agents with a broad spectrum \&f activity, such as metronidazole, gentamicin an penicillin. These should be continued until the primary source of infection has been identified and the sensitivity of the causative bacteria determined. The latter can usually be accomplished in a few days by a technique combining selective culture wi direct sensitivity testing (Ingham et al., 1978a). this time chemotherapy may, if necessary, modified and the primary source extirpated.

Should the nature of the bacterial flora indicate possible dental focus as the primary source of infection it is essential that a dental opinion obtained, as deep-seated dental sepsis may only revealed by specialized techniques, such as intra-ora] X-rays.

\section{Acknowledgments}

We are grateful to $\mathrm{Mr}$ R. M. Kalbag for permission publish details of this case and to Mrs D. Tharagonnet for expert technical assistance.

\section{References}

BAUER, W.H. (1943) Maxillary sinusitis of dental origiz. American Journal of Orthodontics and Oral Surgery, 24 131. 
Cowan, S.T. \& SteEL, K.J. (1974) Manual for the Identifcation of Medical Bacteria (Ed by Cowan, S.T.), 2nd edn. Cambridge University Press.

De Louvois, J., Gortvai, P. \& Hurley, R. (1977) Bacteriology of abscesses of the central nervous system: a multicentre prospective study. British Medical Journal, 2,981 .

Duerden, B.I., Holbrook, W.P., Collee, J.G. \& Watt, B. (1976) The characterisation of clinically important Gram-negative anaerobic bacilli by conventional bacteriological tests. Journal of Applied Bacteriology, 40, 163.

Gray's ANatomy (1967) (Ed by Davies, D.V.), 34th edn, p. 1282. Longman, London.

HACKMAN, A.S. \& Wilkins, T.D. (1976) Influence of penicillinase production by strains of Bacteroides melaninogenicus and Bacteroides oralis on penicillin therapy of an experimental mixed anaerobic infection in mice. Archives of Oral Biology, 21, 385.

Hollin, S.A., HAYASHI, H. \& Gross, S.W. (1967) Intracranial abscesses of odontogenic origin. Oral Surgery, Oral Medicine and Oral Pathology, 23, 277.
Ingham, H.R., Dutton, J., Sisson, P.R., Sprott, M.S. \& SELKON, J.B. (1978a) An aid to the preliminary identification of non-sporing anaerobes. Journal of Clinical Pathology, 31, 806.

Ingham, H.R., High, A.S., Kalbag, R.M., Sengupta, R.P., Tharagonnet, D. \& Selkon, J.B. (1978b) Abscesses of the frontal lobe of the brain secondary to covert dental sepsis. Lancet, ii, 497.

Maloney, P.L. (1968) Maxillary sinusitis of odontogenic origin. Journal of the Canadian Dental Association, 34, 591.

Pinkus, G. Veto, G. \& Braude, A.I. (1968) Bacteroides penicillinase. Journal of Bacteriology, 96, 1437.

Sabiston, C.B., Grigsby, W.R. \& Segerstrom, M.T. (1976) Bacterial study of pyogenic infection of dental origin. Oral Surgery, 41, 430.

Tharagonnet, D., Sisson, P.R., Roxby, C.M., Ingham, H.R. \& Selkon, J.B. (1977) The API ZYM system in the identification of Gram-negative anaerobes. Journal of Clinical Pathology, 30, 505. 